FACTA UNIVERSITATIS

Series: Physical Education and Sport, Vol. 16, No 2, 2018, pp. 365 - 373

https://doi.org/10.22190/FUPES180820033T

Research article

\title{
DIFFERENCES IN GOAL SCORING AND MINUTES OF SCORING BETWEEN TWO EUROPEAN CHAMPIONSHIPS, ONE AMONG 16 TEAMS (EURO 2012) AND THE OTHER AMONG 24 TEAMS (EURO 2016)
}

UDC 796.332.093(4)

\author{
Theoharis Tousios 1 , Yiannis Michailidis' ${ }^{1}$, Athanasios Mandroukas ${ }^{2}$, \\ Dimitrios Mikikis', Thomas Metaxas ${ }^{1}$ \\ ${ }^{1}$ Department of Physical Education and Sports Sciences, Aristotle University of \\ Thessaloniki, Thessaloniki, Greece \\ ${ }^{2}$ Faculty of Physical Education and Sport, Charles University, Prague, Czech Republic
}

\begin{abstract}
The purpose of this study was to record and compare the goal scoring patterns and the minutes of the game that goals were scored between two Euro Cups (2012 and 2016). All matches (n=82) of both the Euro Cups were video taped and analyzed using the sport software Sportscout. Chi-square methods were used for the data analysis and the level of significance was set at $p<0.05$. The team that scored the first goal in a match was the winner of that match 70.97\% of the time in Euro 2012 and $72 \%$ in Euro 2016. In open play, the highs of all the actions were more frequent prior to a goal which involved a cross or a through pass. The 15-min analysis showed that the most goals (20\%) were scored between the $46^{\text {th }}-60^{\text {th }}$ min of the game in the Euro Cup 2012. Furthermore, in the Euro Cup 2016 the most goals were scored between the $31^{\text {st }} 45^{\text {th }}$ minute $(19 \%), 46^{\text {th }}-60^{\text {th }}$ minute $(19 \%)$ and between the $76^{\text {th }}-90^{\text {th }}$ minute $(18 \%)$. No differences between the Euro Cups observed. The results indicated that coaches have to make sure their teams score first, press in the offensive third and prepare their players well in set plays to be more effective.
\end{abstract}

Key words: soccer, goal, video-analysis, ball-recovery, win

Received August 20, 2018 / Accepted September 20, 2018 Corresponding author: Theoharis Tousios Aristotle University of Thessaloniki, Thessaloniki 54124 , Greece Phone: +30 2310996000 •E-mail: tousiostheo@ gmail.com 


\section{INTRODUCTION}

Soccer is one of the most famous sports in the world with more than 265 million athletes and even more fans. This means that more than $4 \%$ of the world's population participates in soccer in some way. This fact has led to a lot of businesses getting involved in soccer by investing large sums of money. It should also be mentioned that in the past10 years the invested amount of money has almost doubled. During the soccer season 2006-2007, 13.6 billion euros were invested and during the 2015-2016 soccer season, 24.6 billion euros were invested. A significant percentage of this money was given to the teams, depending on their accomplishments.

The money helped the teams to develop technologies which could increase their performance. One of these was the video analysis of a match which assists a soccer coach to recall the significant points of a match and give feedback to his players during half time or at the end of a match (Franks \& Miller, 1986). Nowadays, monitoring systems can provide training staff with a lot of information in real time allowing the coach and his assistants to choose which information is significant to be used.

A goal is the most studied variable because it is directly linked to the success of a team (Cachay \& Thiel, 2000). A lot of studies have examined the characteristics of goals that were scored in tournaments (Jinshan, Xiakone, Yamanaka, \& Matsumoto, 1993; Michailidis, Michailidis, Papaiakovou, \& Papaiakovou, 2004) and if goal scoring is affected by time (Ali, Katis, Patsika, \& Kellis, 2015; Michailidis et al., 2004; Michailidis, 2014). This kind of analysis helps coaches and trainers to understand the evolution of soccer and to prepare teams more effectively, although it is not clear whether time affects scoring or not as some studies have mentioned that goal scoring patterns are time dependent (Abt, Dickson, \& Mummery, 2012; Jinshan et al., 1993; Ali et al., 2015; Michailidis et al., 2004), while others state that they are not (Yiannakos \& Armatas, 2006; Armatas \& Yiannakos, 2007). Another popular performance indicator in soccer is the location of ball recovery in a match (Lago-Peñas \& Lago-Ballesteros, 2011). Ball recovery means the end of the defense and the start of the offence of a team (Armatas, Yiannakos, Zaggelidis, Skoufas, Papadopoulou \& Fragkos, 2009).

The European Championship has been held every four years since 1960 and it is only second to the most watched soccer tournament in the world, after the FIFA World Cup. At the start of this tournament, only four teams participated compared to the eight teams which competed in the 1980 European Championship. Sixteen years later the number of teams increased yet again to 16 and in 2008 UEFA decided on the expansion of the tournament to 24 teams. This rise of the number of teams has led to an extra knock out match in comparison to the tournament in the past which involved the participation of 16 teams.

In the present study, goal scoring patterns and time of scoring were compared between Euro 2012 (16 teams) and Euro 2016 (24 teams). In addition, if the team which scored the first goal won the match and if the location of ball recovery had a different impact in goal scoring was also analyzed. 


\section{METHODS}

\section{Sample}

The sample was taken from a total of 82 matches which were played in the group stage and knockout phase of Euro 2012 ( $n=31$ matches) and 2016 ( $n=51$ matches). All the soccer matches were video analyzed with the sport software Sportscout. The study was based on the researcher's personal observation according to Lames $(1991,1994)$ and Singer \& Willimczik (2002). Every match was analyzed by two experienced observers who were specially trained as far as the accuracy and reliability of the data recording was concerned.

\section{Statistical analysis}

All of the data were analyzed using the statistical package for PC SPSS 16.0. Furthermore, a Chi-square analysis was used to determine the statistically significant differences, and the level of significance was set at $\mathrm{p}<0.05$. Last but not least, descriptive statistics consisting of a frequency distribution was used.

\section{RESULTS}

The result from the statistical analysis showed that the team that scored the first goal won the match $70.97 \%$ of the time in Euro $2012\left(\mathrm{X}^{2}=7.759, \mathrm{p}<0.01\right)$ and $72 \%$ of the time in Euro $2016\left(X^{2}=51.000, p<0.001\right)$. There were no significant differences between the two Euros.

In Euro 2012, goal scores following a through pass and a cross appear more frequently than in other categories $\left(X^{2}=56.21, \mathrm{p}<0.001\right)$. More specifically, $35 \%$ of the goals compared to $25 \%$ scored after a through pass and all other patterns had percentages lower than $12 \%$. In Euro 2016, 27\% of the goals were scored after a cross, $17 \%$ and $15 \%$ following a long shot and a through pass respectively $\left(\mathrm{X}^{2}=24.425, \mathrm{p}<0.01\right)$. The rest of the patterns of goal scoring and percentages were lower than $12 \%$. More details are presented in Figure 1A. Lastly, there were no differences between the two Euro Cups $\left(X^{2}=9.181, p>0.05\right)$. The rest of the patterns of goal scoring had percentages lower than $12 \%$. More details are presented in Figure 1A. Lastly, there were no differences between the two Euros $\left(X^{2}=9.181, p>0.05\right)$.

Set play scoring patterns for Euro 2012 were not statistically different $\left(X^{2}=6.500\right.$, p>0.05). $38 \%$ of the goals were scored after a corner kick and $31 \%$ were scored after an indirect foul. Similar results were displayed in Euro 2016 where $37 \%$ of the goals were scored after a corner kick, $19 \%$ after an indirect foul and $25 \%$ following a penalty kick $\left(\mathrm{X}^{2}=9.250, \mathrm{p}>0.05\right)$. The results are presented in Figure 1B. There were no differences between the two Euro Cups $\left(\mathrm{X}^{2}=1.309, \mathrm{p}>0.05\right)$. Additionally, no differences were observed between the two Euro Cups in the total number of goals that were scored in open or set play $\left(X^{2}=2.009, p>0.05\right)$.

In Euro 2012, 79\% of the goals were scored during open play $\left(X^{2}=16.010, p<0.001\right)$ in comparison to Euro 2016 where $70 \%$ were scored during open play $\left(X^{2}=16.010, p<0.001\right)$ (Figure 1C). 

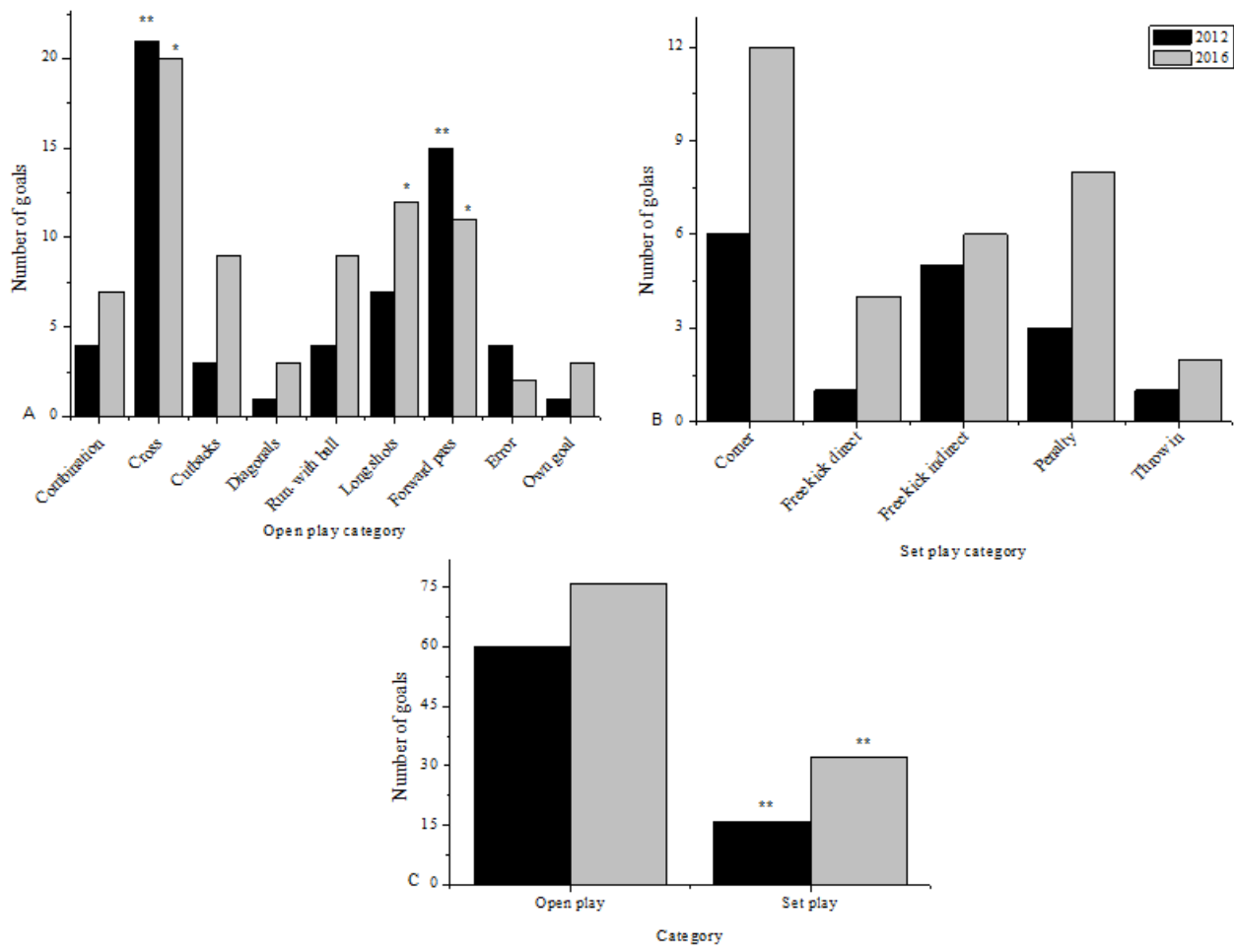

Fig. 1 A. Frequency of actions prior to goal scoring in open play. B. Frequency of actions prior to goal scoring in set play. C. Frequency of goals in open and set play. * denotes difference at $\mathrm{p}<0.01, *$ denotes difference at $\mathrm{p}<0.001$.

In the first half of the two Euro Cups, $41 \%$ of the total goals were scored and there were no differences between the two halves $\left(X^{2}=2.579, p>0.05\right.$ and $X^{2}=3.374, p>0.05$ for Euro 2012 and Euro 2016 respectively).

No statistical differences were found among the minutes that the goals were scored in the first half and the second half of the games of the two Euro Cups ( $\mathrm{p}>0.05$ ) (Figure 2A).

As far as the 15-min analysis of the goals in Euro 2012 is concerned, it is shown that the majority of the goals were scored between the $46^{\text {th }}$ and $60^{\text {th }}$ minute of the game $(20 \%)$. However, the extra time periods were excluded and the significant differences were observed in the frequency of goal scoring during the $1^{\text {st }}$ to the $15^{\text {th }}$ minute of the game $(\mathrm{p}<0.05)$. Moreover, in Euro 2016 the most goals were scored between the $31^{\mathrm{st}}$ and $45^{\mathrm{th}}$ min $(19 \%), 46^{\text {th }}-60^{\text {th }} \min (20 \%)$ and $76^{\text {th }}-90^{\text {th }} \min (18 \%)$. More details entailing the minutes of the game that the goals were scored and frequency of scoring is presented in Figure 2B. Finally, no differences were observed between the two Euro Cups $\left(X^{2}=6.306, p>0.05\right)$. 

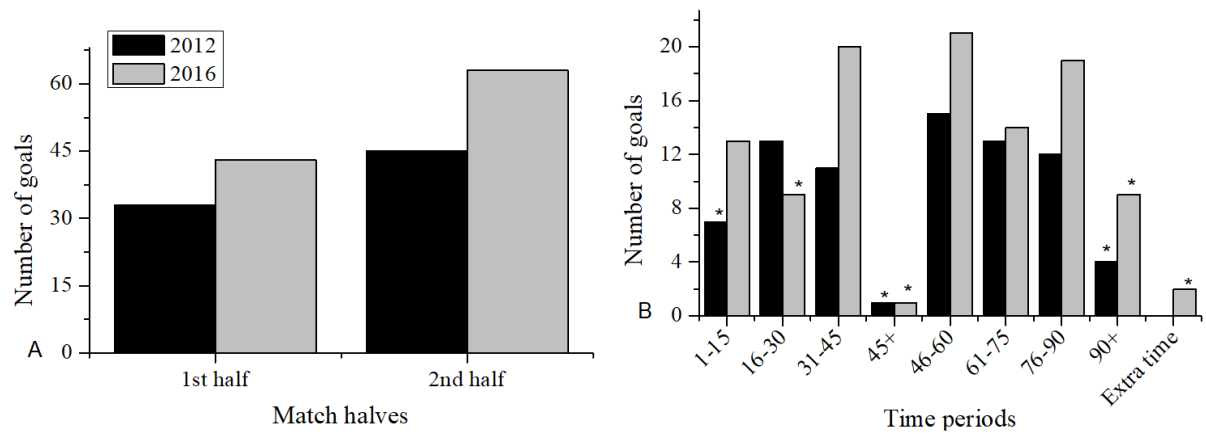

Fig. 2 A Frequency of goal scoring / 45 min in two European Championships. B. Frequency of goal scoring / $15 \mathrm{~min}$ in two European Championships. *denotes difference at $\mathrm{p}<0.05$.

The results of the statistical analysis showed that in both Euro Cups most goals were scored after the recovery of the ball in the offensive third of the field. More specifically, in Euro 2012, 43\% $\left(X^{2}=7.921, p<0.05\right.$ and in Euro 2016, 47\% $\left(X^{2}=12.500, p<0.01\right)$ of the goals came from ball recovery in the offensive third. However, between the two Euro Cups no statistical differences were observed ( $>0.05$ ) (Figure 3).

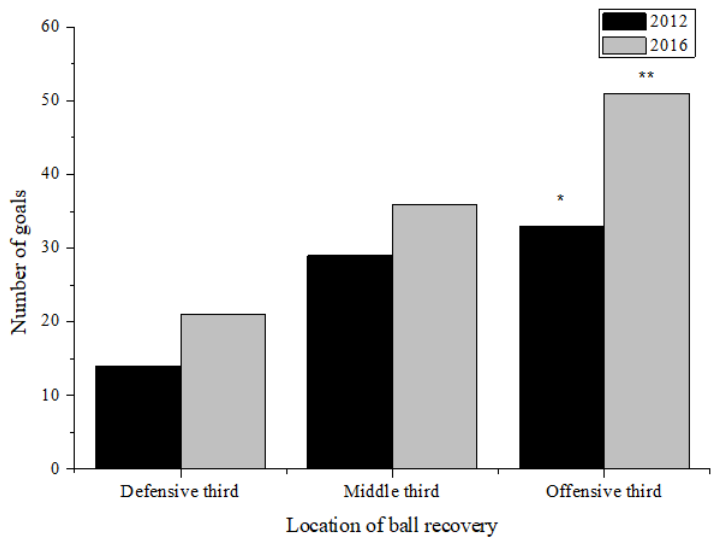

Fig. 3 Frequency of the location of ball recovery prior

to goal scoring in two European Championships.

$*$ denotes difference at $\mathrm{p}<0.05, * *$ denotes difference at $\mathrm{p}<0.01)$.

\section{DISCUSSION}

The purpose of this study was to record and compare the goal scoring patterns and the minutes of the game which the goals were scored between the two Euro Cups (2012 and 2016). Additionally, the impact that the first goal in the match had on the outcome was studied, in addition to the relativity of the location of ball recovery when it comes scoring 
goals. The results of the present study indicate that the team which scored the first goal had more chances of winning the match. Furthermore, most goals were scored following open play with the use of a cross or a through pass. Moreover, in the two Euro Cups second halves presented an increased frequency of goal scoring. As far as the 15-min analysis was concerned, more goals were presented in the time periods between the $46^{\text {th }}$ and $60^{\text {th }}$ minute. Finally, the ball recovery in the offensive third helped teams to score more goals than ball recovery in the other two zones.

Results similar to ours concerning the impact of the first goal in the outcome were mentioned in other studies as well (Leite 2013; Michailidis, Michaildis, \& Primpa, 2013). Armatas and Yiannakos (2010) mentioned that in World Cup of 2006 that the team that scored first won the match $73.21 \%$ of the time and in another study concerning the World Cup 2014, Michailidis (2014) mentioned that the team that scored first won $75.44 \%$ of the time. Scoring the first goal can influence the players' psychology and help them to play with more self-confidence and passion (Jones \& Harwood, 2008; Olsen \& Larsen, 1997). Additionally, when a team wins in reference to time, it can change its tactical strategy and give more attention to defense (Njororai, 2007).

In open play, most goals were scored following a cross, a through pass or a long shot. In a study of the Portuguese premier league, Pratas, Volossovitch, \& Carita (2016) mentioned that the teams which performed more shots, scored the first goal earlier in the match. The high percentage of cross as the last act prior to scoring a goal was mentioned by other studies as well (Michailidis, Michailidis, Mitrotasios, \& Papanikolaou, 2013; Mitrotasios \& Armatas, 2014; Smith \& Lyons, 2017). In a study of World Cups between 2002-2014, Smith \& Lyons (2017) mentioned that a through pass was the most successful strategy to score a goal. Nevertheless, some other last actions prior the goals were a short pass (Mitrotasios \& Armatas, 2014) and a long pass (Yiannakos \& Armatas, 2006). Nowadays, teams are defense organized, making it difficult for an offense team to score a goal. Cross is a tactical action that helps offense teams to break down the opponents' defense block. In addition, small through passes can be used for the same purpose but it is more difficult for the offense player to find space for a shot as there is usually a large number of opponents gathered in the central axon of the field. Lastly, defense players tend to make more mistakes after a side cross as they concentrate more on the ball than on their opponent's actions (Michailidis et al., 2013).

As mentioned earlier, 79\% of the goals in Euro 2012 and 70\% of the goals in Euro 2016 were scored following open play and the remaining after set plays. Similar results were observed by other studies of World Cups (Mitrotasios \& Armatas, 2014). Moreover, in set plays, defenders had the time to get organized and take the right positions. Additionally, referees cannot watch all the players in the box on every occasion, giving defenders the opportunity to use defense strategies that are against the rules of the game without being punished. What is more, offense players are predictable. All of the above reasons can influence the low frequency of goal scoring with set play in comparison to open play (Njororai, 2004; Roxburgh, 1996).

In addition, in our study of both Euro Cups most goals were scored in the second half of the matches in comparison to the first half, but without statistical differences. Armatas, Yiannakos, \& Sileloglou (2007) mentioned that in World Cups of 1998, 2002 and 2006 more goals were scored in the second half as well. In another study concerning World Cups, Leite (2013) observed that $54.4 \%$ of the goals were scored in the second half. 
Similar results in reference to World Cups and Euro Cups were mentioned by other researchers as well (Michailidis, 2014; Mitrotasios \& Armatas, 2014; Njororai, 2004; Yiannakos \& Armatas, 2006).

Moreover, the location of ball recovery seems to play a significant role in the pursuit of scoring. In Euro 2012, $43 \%$ of the goals were scored following ball recovery in the offensive third, and in Euro 2016 there was a 4\% increase (47\%). Smith \& Lyons (2017), in World Cups between 2002 and 2014, observed that most of the goals were scored following ball recovery in the central third part of the field. In the technical report of the Champions League 2016-2017 it was mentioned that 184 goals out of a total of 300 were scored following ball recovery in the offensive third, as it was shown in the present study. In a recent study, Miyazawa, Keika, Sheahan \& Ichikawa (2017) mentioned that the zone in front of the center line was the most common zone for scoring in the Japanese professional soccer league. This is a trend in the evolution of soccer when the teams making an offense play lose the ball immediately press the opponent.

Additionally, in Euro 2012, the extra time periods were excluded. The period of 0-15 minutes showed that there was a lower frequency of goal scoring $(9 \%)$. The frequency in this period is different from the other periods. In Euro 2016, most goals were scored in the time period between 31-60 minutes and 76-90 minutes. The higher frequency of scoring goals in the last 15-min period was also mentioned in other studies (Njororai, 2004; Armatas et al., 2007). Furthermore, in other 15-min periods of the second half high frequencies of scoring goals were observed (Michailidis, 2014; Njororai, 2004). The large number of goals in the last 15 minutes can be explained by a lack of concentration in the players (Abt et al., 2002), the appearance of fatigue and the coaches' tactical strategies. Many studies have mentioned that in the second half players cover less distance (Mohr, Krustrup, \& Bangsbo, 2003). Moreover, the frequency of high intensity actions were reduced toward the end of the game (Krustrup, Mohr, Steensberg, Bencke, Kjaer, \& Bangsbo, 2006). These elements indicate that fatigue can influence actions that are important to abstain a goal. Fatigue, along with dehydration, may also contribute to the lack of concentration (Magal et al., 2003) which is crucial when it comes to preventing goal scoring by an opponent. Additionally, in knock out matches coaches can change their strategy in order to achieve a respectable score for their team. This implies that during the last minutes, teams can press the opponent to score a goal.

\section{CONCLUSION}

The teams have to try to score first in these kinds of tournaments because in this way they increase their chances of winning the match. Also, ball recovery in the offensive third seems to be a trend in the evolution of soccer which means that the teams have been preparing to press the opponent in this area in view of the fact that by winning the ball there they are closer to the opponents' goal. Additionally, the greater frequency of goals which has been observed at the second half depends on a lot of factors such as fatigue, tactical roles and lack of concentration. Finally, coaches need to pay a lot of attention at the players' fitness since it is needed for the players to be able to pressure their opponents high despite the fatigue during the last minutes of the game. 


\section{REFERENCES}

Abt, G.A., Dickson, G., \& Mummery, W.K. (2002). Goal scoring patterns over the course of a match: An analysis of the Australian National Soccer League. In W. Spinks, T., Reilly, \& A, Murphy (Eds.), Science and Football IV, (pp. 107-111), Routledge London.

Ali, M.F.M., Katis, A., Patsika, G., \& Kellis, E. (2015). Goal scoring characteristics in soccer: Are they technique and time dependent? Asia Pacific Journal of Advanced Business and Social Studies, 1(1), 186-194.

Armatas, V., \& Yiannakos, A. (2007). Record and evaluation of set-plays in European Football Championship in Portugal 2004. Inquiries in Sport \& Physical Education, 5(2), 302-307.

Armatas V. \& Yiannakos A. (2010). Analysis and evaluation of goals scored in 2006 World Cup. Journal of Sport and Health Research. 2(2), 119-128.

Armatas, V., Yiannakos, A., \& Sileloglou, P. (2007). Relationship between time and goal scoring in soccer games: Analysis of three World Cups. International Journal of Performance Analysis in Sport, 7(2), 48-58.

Armatas, V., Yiannakos, A., Zaggelidis, G., Skoufas, D., Papadopoulou, S., \& Fragkos, N. (2009). Differences in offensive actions between top and last teams in Greek first soccer division. A retrospective study 19982008. Journal of Physical Education and Sport, 23(2), 1-5.

Cachay, K., \& Thiel, A. (2000). Soziologie des sports (Sociology of sports). Munchen: Juventa-Verlag. In German

Franks, I.M., \& Miller, G. (1986). Eyewitness testimony in sport. Journal of Sport Behavior, 9, 39-45.

Jinshan, X., Xiakone, C., Yamanaka, K., \& Matsumoto, M. (1993). Analysis of the goals in the 14th World Cup. In T. Reilly, J., Clarys, \& A., Stibbe (Eds.), Science and Football II, (pp. 203-205), E. \& F. Spon, London.

Jones, M., \& Harwood, C. (2008). Psychological momentum within competitive soccer: Players' perspectives. Journal of Applied Sport Psychology, 20, 57-72.

Krustrup, P., Mohr, M., Steensberg, A., Bencke, J., Kjær, M., \& Bangsbo, J. (2006). Muscle and blood metabolites during a soccer game: Implications for sprint performance. Medicine and Science in Sports and Exercise, $38(6), 1-10$.

Lago-Peñas, C., \& Lago-Ballesteros, J. (2011). Game location and team quality effects on performance profiles in professional soccer. Journal of Sports Science \& Medicine, 10(3), 465-471.

Lames, M. (1991). Leistungs diagnostic durch Computer simulation (Performance diagnostics through computer simulation). Frankfurt/Main: Thun. In German

Lames, M. (1994). Systematische Spielbeobachtung (Systematic game observation). Münster: Philippka. In German

Leite, W.S.S. (2013). Analysis of goals in soccer world cups and the determination of the critical phase of the game. Physical Education and Sport 11(3), 247-253.

Magal, M., Webster, M. J., Sistrunk, L.E., Whitehead, M.T., Evans, R.K., \& Boyd, J.C. (2003). Comparison of glycerol and water hydration regimens on tennis-related performance. Medicine and Science in Sports and Exercise, 35, 150-156.

Michailidis, C., Michailidis, Y., Mitrotasios, M., \& Papanikolaou, Z., (2013). Analysis of goals scored in the UEFA Champions' League in the period 2009/2010. Serbian Journal of Sport Science 7(2), 51-55.

Michailidis, C., Michailidis, I., Papaiakovou, G., \& Papaiakovou, I. (2004). Analysis and evaluation of way and place that goals were achieved during the European Champions League of Football 2002-2003. Sports Organization, 2(1), 48-54.

Michailidis, Y. (2014). Analysis of goals scored in the 2014 World Cup soccer tournament held in Brazil. International Journal of Sport Studies, 4(9), 1017-1026.

Michaildis, Y., Michaildis, C., \& Primpa, E. (2013). Analysis of goals scored in European Championship 2012. Journal of Human Sport and Exercise, 8(2), 367-375.

Mitrotasios, M., \& Armatas, V. (2014). Analysis of goal scoring patterns in the 2012 European Football Championship. The Sports Journal, 19.

Miyazawa, T., Keika, M., Sheahan, J.P., \& Ichikawa, D. (2017). Effect of opponent quality on goal patterns from direct play in Japanese professional soccer. International Journal of Sports Science, 7(5), 177-183.

Mohr, M., Krustrup, P., \& Bangsbo, J. (2003). Match performance of high-standard soccer players with special reference to development of fatigue. Journal of Sports Sciences, 21, 519-528.

Njororai, W.W.S. (2004). Analysis of the goals scored at the 17th World Cup Soccer Tournament in South KoreaJapan 2002. African Journal for Physical Health Education, Recreation and Dance, 10(4), 326-332.

Njororai, W.W.S. (2007). Scoring goals. What the coach should know about the timing. Soccer Journal, 11/12: 34-36.

Olsen, E., \& Larsen, O. (1997). Use of match analysis by coaches. In T. Reilly, J.,Bangsbo, \& M., Hughes (Eds.). Science and football III, (pp. 209-220), E. \& F. Spon, London. 
Pratas, J.M., Volossovitch, A., \& Carita, A.I. (2016). The effect of performance indicators on the time the first goal is scored in football matches. International Journal of Performance Analysis in Sport, 16(1), 347-354.

Roxburgh, A. (1996). Euro' 96 Technical Report. Nyon: UEFA.

Singer, R., \& Willimczik, K. (2002). Sozial wissen schaftliche Forschungs methoden in der Sport wissenschaft (Social science research methods in sports science). Hamburg: Czwalina. The goals were achieved during the European Champions League of Football 2002-2003. Sports Organ. In German

Smith, R., \& Lyons, K. (2017). A strategic analysis of goals scored in open play in four FIFA World Cup football championships between 2002 and 2014. International Journal of Sports Science \& Coaching, 12(3), 398-403.

Yiannakos, A., \& Armatas, V. (2006). Evaluation of the goal scoring patterns in European Championship in Portugal 2004. International Journal of Performance Analysis in Sport, 6(1), 178-188.

\section{RAZLIKE U POSTIGNUTIM GOLOVIMA I MINUTIMA IGRE NA DVA EVROPSKA PRVENSTVA IZMEĐU 16 TIMA (EURO 2012) I IZMEĐU 24 TIMA (EURO 2016)}

Cilj istraživanja bio je da se odrede i porede načini postizanja bodova i minuta igre tokom kojih su ti golovi postignuti na primeru dva evropska kupa (2012 and 2016). Sve utakmice $(n=82)$ tokom oba evropska kupa snimljene su i analizirane sportskim softverom Sportscout. Chi-square metode su prvo upotrebljene za analizu podataka, a nivo značajnosti bio je $p<0.05$. Tim koji je osvojio prvi bod tokom utakmice je u 70.97\% slučajeva bio pobednik utakmice na Euro 2012 i u 72\% slučajeva na Euro 2016. Tokom same utakmice, vrhunac akcija bio je češći pre gola tokom krosa ili prilikom dodavanja. Analiza 15 min pokazala je da je većina golova (20\%) postignuta između 46. i 60. min igre tokom Euro Cup 2012. Tokom Euro Cup 2016 većina golova postignuta je između 31. i 45. $\min (19 \%)$, 46. i 60. $\min (19 \%)$ i između 76. $i$ 90. $\min (18 \%)$. Nije bilo razlika između dva evropska kupa. Rezultati ukazuju na to da bi treneri trebalo da svoje timove savetuju da prvi daju golove, napadaju na trećini terena i pripreme svoje igrače kako bi bili efikasniji.

Ključne reči: fudbal, gol, video analiza, preuzimanje lopte, pobeda 